\title{
PUSH AND PULL FACTORS OF SENIOR TRAVELERS: THE LINGERING INFLUENCE OF PAST RESTRICTIONS
}

\section{ČIMBENICI GURANJA I PRIVLAČENJA STARIJIH PUTNIKA: ZADRŽANI UTJECAJ PROŠLIH OGRANIČENJA}

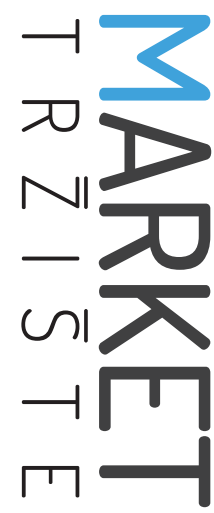

\author{
Market-Tržište \\ Vol. 29, No. 1, 2017, pp. 93-108 \\ UDK 338.484(474.5) \\ DOl http://dx.doi.org/10.22598/mt/2017.29.1.93 \\ Preliminary communication
}

\author{
Sigitas Urbonaviciusa , Tomas Palaima ${ }^{b}$, Indre Radavicienec, Joseph Cheriand \\ a) Vilnius University, Sauletekio al. 9, 10222, Vilnius, LITHUANIA, sigitas.urbonavicius@ef.vu.It \\ b) Vilnius University, Sauletekio al. 9, 10222, Vilnius, LITHUANIA, tomas.palaima@ef.vu.It \\ c) Vilnius University, Sauletekio al. 9, 10222, Vilnius, LITHUANIA, indre.radaviciene@ef.vu.It \\ d) Saint Xavier University, 3700 W. 103 ${ }^{\text {rd }}$ Street, IL 60655, Chicago, USA, cherian@sxu.edu
}

\begin{abstract}
Purpose - The paper analyzes push and pull motivations of senior travelers who have experienced externally imposed travel restrictions earlier in life.

Design/Methodology/Approach - This study is designed to measure push and pull factors of senior travelers, together with positive and negative effects among the respondents who have experienced travel restrictions in their past. The exploration of lingering effects from previous travel restrictions is based on the comparison of findings with prior studies, conducted in environments that did not include the contextual factor of previous travel restrictions. In order to enable the comparison, a selected study is followed by using similar methodological and analytical approaches (e.g. survey sample and methods of analysis). This kind of analysis allowed discovering differences in findings that can be attributed to the lingering effects of past restrictions on travel and that still influence motivations of current senior travelers. The survey was conducted in Lithuania, a country with a memory of historical restrictions on traveling, rather typical of many countries of Eastern Europe and several others in other parts of the world.
\end{abstract}

Findings and implications - The study found that the lingering effects of past restrictions on travel influences

\section{Sažetak}

Svrha - Rad analizira motivacije guranja i privlačenja starijih putnika koji su prije doživjeli izvana nametnuta putna ograničenja.

Metodološki pristup - Istraživanje je osmišljeno tako da mjeri čimbenike guranja i privlačenja starijih putnika zajedno s pozitivnim i negativnim utjecajima među ispitanicima koji su nekad prije iskusili nametnuta putna ograničenja. Istraživanje zadržanih učinaka prethodnih putnih ograničenja temelji se na usporedbi rezultata s ranijim istraživanjima koja su provođena u okruženjima koja nisu uključivala kontekstualni čimbenik prethodnih putnih ograničenja. Kako bi se omogućila usporedba, provedeno istraživanje slijedi odabrano istraživanje sličnog metodološkog i analitičkog pristupa (npr. uzorak ankete i metode analize). Ovaj je način analize omogućio otkrivanje razlika u rezultatima koje mogu biti pripisane zadržanim učincima prošlih putnih ograničenja koji još uvijek utječu na motivacije sadašnjih starijih putnika. Istraživanje je provedeno u Litvi, zemlji koja predstavlja stanje s povijesnim ograničenjima pri putovanju, koja su dosta tipična za mnoge zemlje Istočne Europe i nekoliko slučajeva u drugim dijelovima svijeta.

Rezultati i implikacije - Istraživanje je otkrilo da zadržani učinci putnih ograničenja iz prošlosti utječu na 
current motivations of senior travelers; thus, their motivations differ from those of senior travelers coming from the countries in which there were no travel restrictions in the past. Specifically, the differences include increased importance of travel cost and of personal ego enhancement, and lower sensitivity to comfort.

Limitations - Although the study is based on a sample drawn from one country (Lithuania), the findings may be extended to other countries of Central and Eastern Europe sharing similar historical conditions, especially in terms of travel restrictions in the past.

Originality - The study investigates the unique contextual factor of travel restrictions in travel motivations analysis, and shows the specificity of motivational effects in the countries which experienced past travel restrictions.

Keywords - senior travelers, push and pull motivations, travel restrictions, positive and negative effects, Lithuania trenutnu motivaciju starijih putnika. Stoga se njihove motivacije razlikuju u odnosu na one starijih putnika koji dolaze iz zemalja gdje u prošlosti nije bilo putnih ograničenja. Konkretnije, razlike uključuju povećanu važnost putnih troškova i poboljšanje osobnog ega te smanjenu osjetljivost na udobnost.

Ograničenja - lako se istraživanje temelji na uzroku iz jedne zemlje (Litve), rezultati se mogu proširiti na ostale zemlje Istočne i Centralne Europe koje su imale slične povijesne uvjete, posebice u pogledu putnih ograničenja u prošlosti.

Doprinos - Istražen je jedinstveni kontekstualni čimbenik prošlih ograničenja u motivacijama za putovanjem, a pokazana je i specifičnost motivacijskih učinaka u zemljama u kojima su u prošlosti bila na snazi putna ograničenja.

Ključne riječi - stariji putnici, motivacije guranja i privlačenja, putna ograničenja, pozitivni i negativni utjecaji, Litva 


\section{INTRODUCTION}

Developments of the tourism industry worldwide have created favorable conditions for international travel of citizens in most countries. There are fewer and fewer legal restrictions to limit the mobility of individuals, especially as tourists. Although entry into some countries may be regulated for reasons such as national security or immigration (Neumayer, 2006), restrictions on tourist travel are imposed only in cases of emergency and are typically related to major infectious diseases (Chang, Prytherch Nesbitt, \& Wilder-Smith, 2013). The few instances of political restrictions on tourist travel occur only in a small number of countries, so they have little influence on overall tourism trends worldwide. There are, however, other types of travel restrictions, and different groups of travelers are influenced differently by these restrictions.

The classification of the types of restrictions mainly derives from the theoretical framework of consumer behavior under restrictions. Different product categories are characterized by different types of restrictions in their acquisition and use, and these restrictions can lead to predictable differences in choice; the restrictions to be considered in international travel are externally imposed: political, economic and social restrictions. Political restrictions are the legal restrictions on travel to and from some countries; in softer forms, these restrictions may be manifested in the difficulty in obtaining visas (Neumayer, 2010). Economic restrictions arise from having low purchasing power or not having the funds required for traveling. Social restrictions may take many forms, like a historical dislike in one country for another which may still linger among seniors but may be forgotten by the youth.

Over the last 50 years, the number of older persons has tripled and will at least triple again over the next 50 years (UN, 2001). People aged 65 and over are attractive to the tourism industry because they have buying power and leisure time (Demunter, 2012). Moreover, between 2006 and 2011, "the number of tourists dropped in all age groups except for the $65+$, where $10 \%$ more persons participated in tourism in 2011 than in 2006" (Demunter, 2012, p. 1). The increase in time available for travel is a rather universal characteristic shared by segment of retired travelers worldwide. The absence of political restrictions for travel currently does not depend on the country the travelers come from. The fact that retired people have lower disposable income in comparison to the ones who are employed is more or less universal. However, these generalizations do not apply equally to senior travelers from all countries.

Senior travelers have accumulated their current characteristics over the last 60 or more years. During this period, they lived through very different political and socio-economic conditions, which varied quite a lot among countries and regions. Such differences in conditions led to differences in travel restrictions. It could be expected that the influence of old travel restrictions still lingers in the minds of seniors, even though the restrictions are no longer in place. This allows hypothesizing that the restrictions imposed in the historical past influence motivations of current senior travelers.

Although not uniform, many countries of the former "Communist block", which included countries of the former Soviet Union and Eastern Europe, had varying levels of restrictions on international travel (Kushman, Groth \& Childs, 1980). In this regard, the elderly population of these countries has a certain set of memories and characteristics that are similar, specifically - regarding their approach to international travel.

This is based on three main reasons: first, they lived a major portion of their lives in the period when international tourism was virtually not accessible to a majority of their fellow citizens because of political restrictions (Groth, 2006). This period covered their childhood and youth, thus creating memories that can influence their present feelings about their current situation, and also about travel. The desirability of previously 


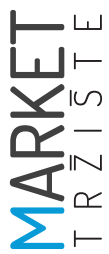

unreachable destinations might make them seem much more desirable today (Lynn, 1992).

Second, the vast majority of the elderly population of these countries had no opportunity to accumulate substantial wealth, unlike in many developed countries where the cost of travel is paid for by savings accumulated over years. This means that they currently have little wealth, and the little they have cannot be spent on travel, which is seen as an unaffordable luxury (Śniadek \& Zajadacz, 2010). Therefore, the cost of the travel offering in these countries has far more importance for the senior travelers who are their citizens; perhaps this factor has to be analyzed separately from other motivators of travel.

Third, while the time resource (i.e. time availability after retirement) of the senior travelers from these countries is similar to that of travelers from other countries, the shortage of funds to pay for the travel might make these people use their leisure time in other ways that allows them to partially quench their thirst for travel. These activities (such as reading, watching TV, reading on the Internet, etc.) help accumulate travel knowledge indirectly, but it does not provide the same personal experience as being "on site". This may also shape push and pull motivations of senior travelers from these countries.

As with the development of any industry, the travel industry too offers an increasing differentiation in price levels, where the lower offers are made to address price-sensitive travelers (Škare \& Gospić, 2015). Thus seniors have more and more opportunities for travel even if they have rather limited financial resources. Because this increased opportunity for travel applies to a large segment of travelers from Central and Eastern Europe, understanding the motivations of this segment can have both economic (practical) and theoretical implications. These implications are derived from travel restrictions imposed in the past, and from the evidence that these restrictions in the form of lingering effects still influence current motivations of seniors to travel.
All this suggests that past experiences with travel restrictions can shape and affect the motivations of senior travelers. Many seniors share this aspect of history; this makes the problem not only theoretically interesting (i.e. from the aspect of how to isolate the impact of prior restrictions), but also economically meaningful (i.e. if many traveling seniors have differences in motivation, there are implications for designing the marketing mix so as to target these seniors more specifically). Therefore, this study seeks to identify the specific differences attributable to the shared experience and lingering effects of travel restrictions in the past.

\section{LITERATURE REVIEW}

\subsection{Senior travelers and their travel behavior}

The categorization of senior consumers varies from using purely chronological, age cut-offs to using the much more subtle concept of the old age identity. The latter is found to be inconsistent and varied culturally and personally, yielding little consensus regarding who should be considered aged (Gatz \& Cotton, 1994). Therefore, in defining this group, population researchers typically use a chronological, age-based definition, in some instances supported by social characteristics (such as being retired). This type of categorization is also common in tourism research, although the lower boundary for the age of this group varies a lot. Analyzing 29 senior travel motivation studies, Patuelli and Nijkamp (2015) found the minimum age varies from 50 to 65 years old. The other characteristics of senior travelers (such as increased availability of time for traveling after retirement) suggest the suitable minimum age of 60 or higher, depending on the retirement age in the studied country. This concept is widely accepted (Horneman, Carter, Wei \& Ruys, 2002; Jang \& Wu, 2006; Lee \& Tideswell, 2005; Moal-Ulvoas \& Taylor, 2014; Nikitina \& Vorontsova, 2015; Zimmer, Brayley \& Searle, 1995).

The age and social status of senior citizens have a significant influence on their behav- 
iors regarding the choice and consumption of products and services both individually and in groups (Barnhart \& Peñaloza, 2013). With regard to travel, seniors have been found to differ from others in information search (Patterson, 2007), in travel frequency (Losada, Alén, Domínguez \& Nicolau, 2016), and in the duration of stay at a destination (Alén, Nicolau, Losada \& Domínguez, 2014).

Seniors often prefer air travel, especially since low cost airlines have become available (Losada et al., 2016). Since international travel to an unfamiliar environment might be unattractive for seniors, many of them consider group packages with complex services included (Kazeminia, Del Chiappa \& Jafari, 2015; Wang, 2006). It has been observed that senior travelers will more often engage in healthy behavior (healthy eating, using health facilities), because of the want to have the health and leisure needed to have an enjoyable and meaningful life during retirement (Lu, Hung, Wang, Schuett \& Hu, 2016). Typically, senior travelers prefer a higher level of comfort and perceive safety as an important factor. However, simultaneously they show a desire for novelty and search for authentic experiences (Vojvodic, 2015).

All the above mentioned aspects of senior travelers' preferences and behaviors are now being explained by reasons ranging from those related to individual's health and economic status on the one hand (Sangpikul, 2008b), to others such as the traveling format and specifics of the destination on the other hand (Alén et al., 2014). In explaining senior travelers' behavior, these external factors can be augmented by deeper explanations that are based on the motivations of senior travelers.

\subsection{Seniors' travel motivation}

The set of travel motivations is one of the very important aspects of travel behaviors, since motivations form the basis of majority of travelers' decisions. This both calls for seeking a deeper understanding of the types of motivations and encourages the development of motivation typologies.

Of the many classifications of travel motivations, the one that divides factors into push and pull motivations seems to be applicable to a broad scope of studies and is therefore widely accepted. Crompton and McKay (1997) first proposed grouping motivations into the categories of pull and push factors, and this concept continues to be used by numerous other researchers (Jang \& Wu, 2006). According to Patuelli and Nijkamp (2015), push motivation is internal and refers to the needs and desires which are not destination-specific. In contrast, pull motivation pertains to external tangible or intangible attributes perceived by potential tourists as destination-specific. Therefore, push motivations are more linked with the overall (general) personal wish to travel that grows from personality and its interaction with the current environment (especially, it that environment is not rich or fulfilling enough). Pull motivations, on the other hand, refer to perceptions about destinations; they may range from very objective reflections of reality to the rather distorted and/or idealistic beliefs about specific sites and/or their environments.

The categorization of motivations into push and pull categories is fully appropriate in the analysis of motivations of senior travelers. Jang and Wu (2006) argue that the travel motivation of seniors entails five push factors (ego-enhancement, self-esteem, knowledge-seeking, relaxation, and socialization) and three pull factors (cleanliness and safety; facilities, event, and cost; and natural and historical sites). A later study by Sangpikul (2008a) puts forward a very similar dimensionality of the seniors' travel motivation, which comprises three push factors (novelty and knowledge-seeking, ego-enhancement, and rest and relaxation) and four pull factors (travel arrangements and facilities; cultural and historical attractions; shopping and leisure activities; and safety cleanliness). In line with the works already reviewed, the meta-analytical study by Patuelli and Nijkamp (2015) concludes 


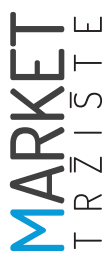

that most frequently travel motivation encompasses five dimensions: (1) culture and nature; (2) experience and adventure; (3) relaxation, well-being, and escape; (4) socialization; and (5) self-esteem and ego-enhancement. Having compared Western and Eastern travel motivations, Le Serre, Legohérel and Weber (2013) outline four dimensions of the seniors' motivation which are relevant to the two types of culture: social, relaxation, intellectual on the one, and sport on the other hand.

\subsection{Affect in traveling motivation}

Previous research (Jang \& Wu, 2006) demonstrates that affect is substantially related to push and pull motivations. Thus, marketing strategies targeting seniors should consider both happy and sad life events, occurring both currently and in the past. Consequently, the concepts of positive and negative affect should be discussed and elucidated more broadly.

According to Watson, Clark and Tellegen (1988, p. 1063), "positive affect (PA) reflects the extent to which a person feels enthusiastic, active, and alert" whereas "negative affect (NA) is a general dimension of subjective distress and un-pleasurable engagement that subsumes a variety of aversive mood states, including anger, contempt, disgust, guilt, fear, and nervousness, with low NA being a state of calm". Further, Watson, Clark and Carey (1988, p. 346) put forward evidence that negative affect (NA) "is a [positive] predictor of psychiatric disorder" which is related to "symptoms and diagnoses both depression and anxiety". On the other hand, the loss of positive affect is related only to depression. In order to measure affect, Watson and others (1988) propose the Positive and Negative Affect Schedule (PANAS) consisting of two 10-item mood scale (Positive Affect: attentive, interested, alert, excited, enthusiastic, inspired, proud, determined, strong, and active; Negative Affect: irritable, alert, ashamed, inspired, nervous, determined, attentive, jittery, active, and afraid). Mroczek and Kolarz (1998) argue that there is a relationship between af- fect and age. Moreover, the authors explain that, in order to understand this relationship, it is necessary to consider personality, contextual and socio-demographic factors. The study by Mroczek and Kolarz (1998) conceptualizes affect as a two-dimensional construct entailing six items of positive affect (cheerful, in good spirits, extremely happy, calm and peaceful, satisfied, full of life) and six items of Negative Affect (so sad nothing could cheer you up, nervous, restless or fidgety, hopeless, everything was an effort, worthless). The work of Larsen and Ketelaar (1991, p. 138) corroborates the view of Gray (1981) in that "extroverts (compared with introverts) [...] show heightened reactivity to positive (but not negative) mood-induction procedures, whereas neurotics (compared with stable individuals) [...] show heightened reactivity to induction procedures for negative (but not positive) mood". The study employed six adjectives to operationalize negative affect (distressed, fearful, nervous, jittery, anxious, and annoyed) and six adjectives to measure positive affect (enthusiastic, excited, elated, peppy, euphoric, and lively). On the basis of factor analysis, Diener, Larsen, Levine and Emmons (1985) use four items to measure positive affect (happy, pleased, joyful, and enjoyment) and five items to gauge negative affect (unhappy, depressed/blue, frustrated, angry/hostile, and worried, anxious and fearful fun).

\subsection{Restricting factors in senior travel}

Motivation and affect are important and rather universal influences on human behavior, including senior travel. However, this study investigates such influences in the context of a specific factor, where travel restrictions only exist in the senior traveler's memory, not in currently existing reality.

The limiting factors within the travel context have been perhaps best conceptualized by the hierarchical model (Crawford \& Godbey, 1987; Crawford, Jackson \& Godbey, 1991) and revisited by the authors 20 years later with their additional insights (Godbey, Crawford \& Shen, 2010). 
The integrated model suggested a sequential, hierarchical series of constraints levels, including three propositions about the nature, operation, and sources of constraints. Authors also suggested the manner in which these constraints affect choices among people who are already participating in leisure or travel behaviors.

Historically, citizens of a large group of countries from Eastern Europe and the former Soviet Union have experienced political restrictions on international travel (Groth, 2006). In some instances, the restrictions were so heavy that individuals considered international tourism all but non-existent. This restriction was a constant reminder of what one could not have, thus increasing the potential attractiveness of foreign travel (Pratkanis \& Farquhar, 1992). In addition, people who had succeeded in traveling abroad, were considered unique or even superior to other members of society, e.g. if one had traveled to a distant country or to a country with a different political/economic system (Kushman et al., 1980). Therefore, almost unavailable options for travel acquired even higher attractiveness, backed up by the need for uniqueness and status-seeking factors. Those who traveled could express their uniqueness and gained status by displaying goods acquired abroad and telling stories of their travel experiences. Such a socio-political context was typical for many years for a generation that currently includes senior travelers from the above mentioned countries. It allows proposing that such historically experienced and still remembered conditions influence current travel motivations of those senior travelers.

In addition to political restrictions, the seniors from these countries also experienced specific economic hardships: first, a majority of them did not earn enough to afford international tourism (with minor exceptions, such as when tourism itself was an income-earning activity (Zatlin, 2007). Even in the countries where direct restrictions on travel were lower, insufficient income levels coupled with restricted convertibility of the local currencies did not allow for funds to be used for travel. Subsequent economic collapses often erased the remaining savings; thus, current seniors in those countries have significantly fewer funds for travel than their cohorts living in more stable economies. This is the obvious economic restriction that has been present during prolonged periods of life of current seniors, and it still lingers in their memory. This has an important influence on travel motivations of seniors, and increases perceived importance of traveling costs.

Historical restrictions that increase attractiveness of international travel, together with economic restrictions (historical and current scarcity of funds for travel), might also have additional effects on travel motivations. Senior travelers from the analyzed countries could be less demanding when it comes to comfort of trip and stay; however, they could see travel as an opportunity to enrich oneself with new knowledge, experiences and even ego-enhancement.

\section{METHODOLOGY}

\subsection{Data collection}

The overall logic is that the lingering effects of past travel restrictions may be isolated and identified if a study replicates the concepts and methods of the studies conducted in an environment in which there were no travel restrictions. Among them, the study by Jang and Wu (2006) was selected as the most suitable for applying this logic. The main criteria for that choice was extensive examination of the push and pull motivations, together with the measurement of affect; the measurement of affect is conceptually important for studying lingering effects because those memories and experiences directly impact affect towards travel. Therefore, without direct replication, the study followed the Jang and Wu study by using similar research instrument and the overall logic of data analysis.

Surveys were used to collect data from senior citizens, who are residents of the two largest cities in Lithuania, when participating in Univer-

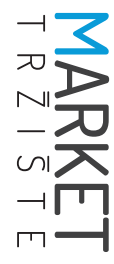


sities of the Third Age. All the participants were retired and above the age of 60 . These senior citizens filled in self-administered questionnaires; 171 responses were suitable for further analysis.

In order to gauge push and pull motivations, as well as positive and negative affect, questionnaire scales from the study of Jang and Wu (2006) were adapted. After the translation of questions, they were tested on a pilot group of respondents in order to ensure the correct understanding of the text. Following practices of other similar studies, no extra testing of psychometric properties of the instrument within the Lithuanian context was done as this study explored the imperfections in measurements via post hoc analysis, by comparing factor loadings with those found in former studies (and, specifically, with the Jang and Wu (2006) study). All the statements were evaluated using a 5-point scale. The push, pull, and affect scales had different anchors. Firstly, the 23 push items were rated on a scale ranging from 1 (strongly disagree) to 5 (strongly agree). Secondly, the 12 pull statements were assessed on a scale ranging from 1 (not important at all) to 5 (very important). Finally, the 6 statements of positive affect and 6 statements of negative affect were evaluated on a scale ranging from 1 (none of the time) to 5 (all of the time). Consistent with the study of Jang and Wu (2006), the questionnaire also included 4 personal characteristic variables: age, gender, self-perceived economic status, and self-perceived health status.

The collected data were analyzed using two steps. Firstly, exploratory factor analysis (principal components) with Varimax rotation was employed in order to assess the dimensionality of the push and pull motivations, as well as of the positive and negative affect scales. Secondly, the identified push and pull dimensions were regressed on personal characteristics of the Lithuanian senior travelers, as well as positive and negative affect, using multiple linear regression.

\subsection{Push and pull motivation factors}

Exploratory factor analysis (principal components) demonstrates that the dimensionality of push motivation is substantially different from the study by Jang and Wu (2006). The emerged factors were named as follows (see Table 1): (1) sightseeing and culture, (2) comfort, (3) relaxed socialization, (4) ego-enhancement, (5) family orientation and relaxation. These factors explain $66 \%$ of the total variance. The factor analysis of pull motivation demonstrates that the underlying structure comprises 3 factors (see Table 2): (1) cleanliness and safety, (2) climate, local events, and sightseeing, and (3) facilities for physical activities. These three factors explain $64.90 \%$ of the total variance. 
TABLE 1: Push factors of Lithuanian seniors

\begin{tabular}{|l|c|c|}
\hline Push factors & $\begin{array}{c}\text { Factor } \\
\text { loadings }\end{array}$ & $\begin{array}{c}\text { Variance } \\
\text { explained }\end{array}$ \\
\hline Factor 1: Sightseeing and culture & & $14.93 \%$ \\
\hline It's important for me to go someplace popular on a trip & .81 & \\
\hline I want to see the things that I don't normally see & .74 & \\
\hline When on a trip, I attend cultural events that I don't have access to at home & .60 & \\
\hline I like to see how people of other cultures live & .42 & \\
\hline Factor 2: Comfort & & $14.66 \%$ \\
\hline $\begin{array}{l}\text { The availability of good restaurants and good food is important in } \\
\text { choosing a trip spot }\end{array}$ & .86 & \\
\hline While on a trip, I want luxury, nice food, and a comfortable place to stay & .80 & \\
\hline On a trip, I like to do the same things that the people there do & .62 & \\
\hline Factor 3: Relaxed socialization & & $13.01 \%$ \\
\hline While on a trip, I want to meet new people and socialize & .77 & \\
\hline There should be no deadlines while on a trip & .75 & \\
\hline Factor 4: Ego-enhancement & & $12.52 \%$ \\
\hline I like to talk about my trip when I get home & .82 & \\
\hline When I go home, I talk to everybody about my trip & .80 & \\
\hline Factor 5: Family-orientation and relaxation & & $11.89 \%$ \\
\hline While on a trip, just resting and relaxing is enough for me & .73 & \\
\hline It is important for me to spend time on a trip with family and friends & .69 & \\
\hline A trip means relaxation and slowing down. & .63 & \\
\hline Total variance explained & & $\mathbf{6 6 . 0 0 \%}$ \\
\hline
\end{tabular}

Note: Tourist motivations were evaluated on the scale of 1: strongly disagree; 2: disagree; 3: neutral; 4: agree; 5: strongly agree.

TABLE 2: Pull factors of Lithuanian seniors

\begin{tabular}{|l|c|c|}
\hline Pull factors & $\begin{array}{c}\text { Factor } \\
\text { loadings }\end{array}$ & $\begin{array}{c}\text { Variance } \\
\text { explained }\end{array}$ \\
\hline Factor 1: Cleanliness and safety & & $25.31 \%$ \\
\hline Standards of hygiene and cleanliness & .75 & \\
\hline Environmental quality of the air, water, and soil & .72 & \\
\hline Safety and security & .71 & \\
\hline $\begin{array}{l}\text { Quality of public transportation services (such as airlines, train service, bus } \\
\text { service) }\end{array}$ & .77 & \\
\hline Factor 2: Climate, local events, and sightseeing & & $19.99 \%$ \\
\hline Good climate & .71 & \\
\hline Local events and activities & .76 & \\
\hline Historical sights & .57 & \\
\hline Outstanding scenery & .66 & \\
\hline Factor 3: Facilities for physical activities & & $19.61 \%$ \\
\hline Facilities for physical activities & .87 & \\
\hline Availability of walking paths & .85 & \\
\hline Total variance explained & & $\mathbf{6 4 . 9 0} \%$ \\
\hline
\end{tabular}

Note: Tourist motivations were evaluated on a scale of 1: not at all important; 2: not very important; 3: neutral; 4: somewhat important; 5: very important. 


\subsection{Positive and negative affect factors}

Although the study by Jang and Wu (2006) did not evaluate the dimensionality of positive and negative affect, certain other studies (e.g. Barclay \& Kiefer, 2014) indicate that such analysis is an appropriate practice. Consequently, 12 items of positive and negative affect have been included into the factor analysis. The present study indicates that the underlying factor structure comprises 4 dimensions: (1) life satisfaction, (2) hopelessness, (3) nervousness, and (4) happiness. The four factors explain $68.81 \%$ of the total variance.

\section{FINDINGS: SENIOR'S TRAVEL MOTIVATION DETERMINANTS}

Push and pull motivations were compared to the overall cost of vacation. As expected, the overall cost of vacation is the most important variable (4.15; see Table 4) which can be regarded as the main restriction to travel. The importance of other push and pull motivations is as follows: cleanliness and safety (4.10); sightseeing and culture (4.01); climate, local events, and sightseeing (3.95); ego-enhancement (3.82); relaxed socialization (3.71); family-orientation and relaxation (3.56); facilities for physical activities (3.06); comfort (2.73).

TABLE 3: Positive and negative affect factors of Lithuanian seniors

\begin{tabular}{|l|c|c|}
\hline Push factors & $\begin{array}{c}\text { Factor } \\
\text { loadings }\end{array}$ & $\begin{array}{c}\text { Variance } \\
\text { explained }\end{array}$ \\
\hline Factor 1: Life satisfaction & .62 & $18.51 \%$ \\
\hline In good spirits & .79 & \\
\hline Calm and peaceful & .61 & \\
\hline Satisfied & .68 & \\
\hline Full of life & & $17.59 \%$ \\
\hline Factor 2: Hopelessness & .76 & \\
\hline So sad that nothing could cheer me up & .80 & \\
\hline Hopeless & .52 & \\
\hline Everything was an effort & & $16.61 \%$ \\
\hline Factor 3: Nervousness & .72 & \\
\hline Nervous & .91 & \\
\hline Restless or fidgety & & $16.09 \%$ \\
\hline Factor4: Happiness & .75 & \\
\hline Cheerful & .72 & \\
\hline Extremely happy & & $\mathbf{6 8 . 8 1} \%$ \\
\hline Total variance explained & & \\
\hline
\end{tabular}

Note: Affect variables were measured on a scale of: 1 (none of the time), 2 (a little of the time), 3 (some of the time), 4 (most of the time), 5 (all of the time). 
TABLE 4: Importance of motivation factors

\begin{tabular}{|l|c|c|}
\hline & Mean & $\begin{array}{c}\text { Std. } \\
\text { Deviation }\end{array}$ \\
\hline Overall cost of vacation & 4.15 & .80 \\
\hline Cleanliness and safety & 4.10 & .58 \\
\hline Sightseeing and culture & 4.01 & .58 \\
\hline $\begin{array}{l}\text { Climate, local events, and } \\
\text { sightseeing }\end{array}$ & 3.95 & .59 \\
\hline Ego-enhancement & 3.82 & .82 \\
\hline Relaxed socialization & 3.71 & .76 \\
\hline $\begin{array}{l}\text { Family-orientation and } \\
\text { relaxation }\end{array}$ & 3.56 & 2.07 \\
\hline $\begin{array}{l}\text { Facilities for physical } \\
\text { activities }\end{array}$ & 3.06 & .86 \\
\hline Comfort & 2.73 & .91 \\
\hline
\end{tabular}

As already mentioned, the current study aimed to estimate how age, gender, economic status, health status, and affect predict push and pull motivations. The study also evaluated the relationships between the socio-demographic variables mentioned and the overall cost of vacation. Consequently, the push and pull dimensions identified, as well as overall cost of vacation, were regressed on the personal characteristics of Lithuanian senior travelers, along with positive and negative affect, using multiple linear regression. As research in push and pull motivations is scarce, the inclusion of independent variables into the regression models according to their theoretical importance was impossible. Consequently, multiple linear regression with a backward method was deemed the most appropriate analysis technique.

Regression models with determination coefficient $\left(R^{2}\right)$ below 10 were excluded from further analysis. The analysis indicates that the socio-demographic variables explain from 1 to .21 of the variance in the push motivation factors (see Table 5). The strongest antecedent of sightseeing and culture is gender (.38). Specifically, female senior tourists are more interested in sightseeing and culture. Other determinants of this outcome are life satisfaction (.36) and self-perceived economic status (.14). Comfort depends on five determinants: happiness (.27), self-perceived economic status (.19), self-perceived health status (.17), age (-.18), and life satisfaction (-.21). The analysis indicates the antecedents of relaxed socialization to be as follows: gender (.3), life satisfaction (.28), and age (.13). Family-orientation and relaxation depends on three variables: happiness (.34), hopelessness (.18), and age (-.16). Finally, ego-enhancement is caused by the following dimensions: gender (.54), life satisfaction (.25), self-perceived economic status (.18), self-perceived health status (.12), and nervousness (-.12). In the last step, an evaluation of the relationships between socio-demographic variables and the overall cost of vacation was performed. The analysis indicates that the model explains 34\% of the variance in this outcome (see Table 5). The importance of the overall cost of vacation depends on 6 variables: nervousness (.38), gender (.2), self-perceived economic status (.16), life satisfaction (.13), happiness (-.21) and hopelessness (-.45). 
TABLE 5: Results of linear regression

\begin{tabular}{|c|c|c|c|c|c|c|}
\hline & & & Dependent & variables & & \\
\hline & $\begin{array}{l}\text { Sightseeing } \\
\text { and culture }\end{array}$ & $\begin{array}{c}\text { Relaxed } \\
\text { socialization }\end{array}$ & $\begin{array}{c}\text { Family- } \\
\text { orientation } \\
\text { and } \\
\text { relaxation }\end{array}$ & \begin{tabular}{|c|} 
Ego- \\
enhancement
\end{tabular} & \begin{tabular}{|c|} 
Climate, \\
local \\
events and \\
sightseeing
\end{tabular} & $\begin{array}{c}\text { Overall } \\
\text { cost of } \\
\text { vacation }\end{array}$ \\
\hline Age & & .13 & -.16 & & & \\
\hline $\begin{array}{l}\text { Self-perceived } \\
\text { economic } \\
\text { status }\end{array}$ & .14 & & & .18 & .34 & .16 \\
\hline $\begin{array}{l}\text { Self-perceived } \\
\text { health status }\end{array}$ & & & & .12 & & \\
\hline $\begin{array}{l}\text { Life } \\
\text { satisfaction }\end{array}$ & .36 & .28 & & .25 & & .13 \\
\hline Hopelessness & & & .18 & & & -.45 \\
\hline Nervousness & & & & -.12 & & .38 \\
\hline Happiness & & & .34 & & & -.21 \\
\hline Gender & .38 & .3 & & .54 & .30 & .2 \\
\hline $\begin{array}{l}\text { Adjusted } \mathbf{R}^{2} \\
\text { values }\end{array}$ & .21 & .12 & .15 & .3 & .16 & .34 \\
\hline
\end{tabular}

\section{DISCUSSION, LIMITATIONS AND RECOMENDATIONS}

This study aims to outline travel motivations of seniors who come from countries that experienced significant travel restrictions in the past. The differences in results that emerge in comparing them with those of similar studies (mainly, through comparison with Jang and Wu, 2006) allow attributing such differences to the impact of restrictions imposed long ago but still lingering in seniors' minds. These results suggest three contributions of this study.

First, the dimensionality of the Lithuanian seniors' motivation was found to have the same structure as the literature had shown. Push motivation comprises five factors (sightseeing and culture; comfort; relaxed socialization; ego-enhancement; family orientation and relaxation) whereas pull motivation contains three dimensions (cleanliness and safety; climate, local events, and sightseeing; and facilities for physical activities). The identified dimensionality of push motivation is very similar to the meta-analytical study by Patuelli and Nijkamp (2015), which concludes that travel motivation most frequently encompasses five dimensions: (1) culture and nature; (2) experience and adventure; (3) relax, well-being, and escape; (4) socialization; and (5) self-esteem and ego-enhancement. On the other hand, the underlying structure of pull motivation identified here is quite similar to the study of Sangpikul (2008a), which puts forward four pull travel motivations (travel arrangements and facilities; cultural and historical attractions; shopping and leisure activities; and safety cleanliness). Thus, seniors who faced historical restrictions had a similar motivational structure as that found in the literature.

Second, this study identifies the importance of push and pull motivations and relates them to the overall cost of vacation. As expected, the overall travel cost is the most important variable (4.15) and can thus be regarded as the main re- 
striction to travel, reflecting the historical realities when the conditions for the accumulation of wealth were not favorable. The importance of other push and pull motivations provides no noticeable differences between analyzed countries and all others (cleanliness and safety (4.10); sightseeing and culture (4.01); climate, local events, and sightseeing (3.95); ego-enhancement (3.82); relaxed socialization (3.71); family-orientation and relaxation (3.56)), except for the two lowest ranked items: facilities for physical activities (3.06) and comfort (2.73). The low need for the facilities for physical activities might be related with a perception of one's health status, which has a twofold influence on that need. The facilities can be highly wanted when they are seen as the means for improving/maintaining heath, or can be viewed as being no longer appropriate for the existing state of health of a senior person (Woo, Kim \& Uysal, 2014). In this survey, the second interpretation was better supported. However, the extremely low importance of the comfort factor is a much more important finding. This stems from the idea that seniors from these countries are ready to give up on any type of comfort in order to make the travel happen. This may be understood as a quite direct echo of the restrictions they have experienced historically.

Finally, the third and the most important contribution stems from an identification of meaningful relationships between motivation factors and other analyzed parameters of senior travelers. The current study aims to estimate how age, gender, economic status, health status, and affect predict push and pull motivations. Among all these, the most important objective is to evaluate the relationships between the socio-demographic variables mentioned and the importance of the overall cost of vacation, presented as a separate pull factor. Consequently, the push and pull dimensions identified, as well as the overall cost of vacation, were regressed on the personal characteristics of the Lithuanian senior travelers and positive and negative affect. The analysis shows the overall cost of vacation to be the most important pull variable, affected by nearly all predictors: nervousness (.38), gender (.2), self-perceived economic status (.16), life satisfaction (.13), happiness (-.21), and hopelessness (-.45). Consequently, the proposed model is the most effective in explaining the importance of the cost factor, which occurs as a result of the historical restrictions experienced. Moreover, the proposed predictors are also very effective in explaining ego-enhancement - another motivation that is clearly related to historical restrictions, when a person making international travels was viewed as a superior member of a society (Kushman et al., 1980). This corroborates the proposition of the study that some aspects of the theory of restricted choice are applicable to the analysis of travel motivations in the context of countries with past restrictions on travel.

In conclusion, the impact of historical restrictions still lingers in the minds of senior travelers and affects the choices that they make. In addition to the importance they give to travel costs (which is to be expected), senior travelers also care about ego enhancement. Being able to boast about having traveled abroad is an antiquated notion that could only have arisen from growing up in situations where that was considered a noteworthy achievement. A sensitivity to travel costs and striving towards ego enhancement forces these senior travelers to compromise on the comfort of travel.

At the same time, the study has obvious limitations that may be reduced by future research on the subject.

First, the survey was conducted in just one country. Although that country has typical characteristics of Central and Eastern Europe crucial to this study (travel restrictions in the past, free traveling opportunities for the current senior population), additional studies in other parts of the region are needed to confirm the validity of the lingering effects observed.

Second, the survey did not concentrate on the segment of seniors who are currently engaged in traveling, thus their actual behavior could not

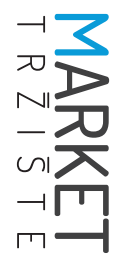


be incorporated into the analysis. This has both positive and negative sides. The positive side is the focus on a broad segment of seniors, most of whom still have virtually no resources for traveling, but who are perfectly able to express their motivations. Concentrating merely on the seniors who are currently traveling would have misrepresented the motivational structure of the overall segment, since the traveling group might differ from others in terms of available resources. However, the linkage of motivations to actual behaviors is always welcome because it helps to gain additional insights. Therefore, this would be another possible direction for future studies on this topic.
Finally, this study only sought to investigate the idea that motivations may be influenced by the lingering effects from the past. There was no attempt to propose hypotheses about concrete influences of that effect. The effect itself is not measured directly, but is observed indirectly through comparison with the studies conducted in the circumstances of no past travel restrictions. Therefore, the next step would be to operationalize the observed effect and test these measured lingering influences of past restrictions for measurement properties and for interactions with other factors.

\section{References}

1. Alén, E., Nicolau, J. L., Losada, N., \& Domínguez, T. (2014). Determinant factors of senior tourists' length of stay. Annals of Tourism Research, 49, 19-32.

2. Barclay, L. J., \& Kiefer, T. (2014). Approach or avoid? Exploring overall justice and the differential effects of positive and negative emotions. Journal of Management, 40(7), 1857-1898.

3. Barnhart, M., \& Peñaloza, L. (2013). Who are you calling old? Negotiating old age identity in the elderly consumption ensemble. Journal of Consumer Research, 39(6), 1133-1153.

4. Chang, F., Prytherch, H., Nesbitt, R. C., \& Wilder-Smith, A. (2013). Hiv-related travel restrictions: Trends and country characteristics. Global Health Action, 6, 1-8.

5. Crawford, D. W., \& Godbey, G. (1987). Reconceptualizing barriers to family leisure. Leisure Sciences, 9(2), 119-127.

6. Crawford, D. W., Jackson, E. L., \& Godbey, G. (1991). A hierarchical model of leisure constraints. Leisure Sciences, 13(4), 309-320.

7. Crompton, J. L., \& McKay, S. L. (1997). Motives of visitors attending festival events. Annals of Tourism Research, 24(2), 425-439.

8. Demunter, C. (2012). Europeans aged 65+ spent a third more on tourism in 2011 compared with 2006. Retrieved from http://ec.europa.eu/eurostat/web/products-statistics-in-focus/-/KS-SF-12-043.

9. Diener, E., Larsen, R. J., Levine, S., \& Emmons, R. A. (1985). Intensity and frequency: Dimensions underlying positive and negative affect. Journal of Personality and Social Psychology, 48(5), $1253-$ 1265.

10. Gatz, M., \& Cotton, B. (1994). Age as a dimension of diversity: The experience of being old. In: J. T. Edison, J. W. Roderick \& D. Birman (Eds.). Human diversity: Perspectives on people in context (pp. 334-358). San Francisco, CA: Jossey-Bass.

11. Godbey, G., Crawford, D. W., \& Shen, X. S. (2010). Assessing hierarchical leisure constraints theory after two decades. Journal of Leisure Research, 42(1), 111.

12. Gray, J. A. (1981). A critique of eysenck's theory of personality. In: H. J. Eysenck (ed.). A model for personality (pp. 246-276). Berlin: Springer Berlin Heidelberg.

13. Groth, A. J. (2006). East and west: Travel and communication under alternate regimes; a research note. Communist and Post-Communist Studies, 39(1), 121-133. 
14. Horneman, L., Carter, R. W., Wei, S., \& Ruys, H. (2002). Profiling the senior traveler: An australian perspective. Journal of Travel Research, 41(1), 23-37.

15. Jang, S., \& Wu, C-M. E. (2006). Seniors' travel motivation and the influential factors: An examination of taiwanese seniors. Tourism Management, 27(2), 306-316.

16. Kazeminia, A., Del Chiappa, G., \& Jafari, J. (2015). Seniors' travel constraints and their coping strategies. Journal of Travel Research, 54(1), 80-93.

17. Kushman, J. E., Groth, A., \& Childs, R. (1980). Political systems and international travel. Social Science Quarterly, 60(4), 604-616.

18. Larsen, R. J., \& Ketelaar, T. (1991). Personality and susceptibility to positive and negative emotional states. Journal of Personality and Social Psychology, 61(1), 132-140.

19. Le Serre, D., Legohérel, P., \& Weber, K. (2013). Seniors' motivations and perceived risks: A cross-cultural study. Journal of International Consumer Marketing, 25(2), 61-79.

20. Lee, S. H., \& Tideswell, C. (2005). Understanding attitudes towards leisure travel and the constraints faced by senior koreans. Journal of Vacation Marketing, 11(3), 249-263.

21. Losada, N., Alén, E., Domínguez, T., \& Nicolau, J. L. (2016). Travel frequency of seniors tourists. Tourism Management, 53, 88-95.

22. Lu, J., Hung, K., Wang, L., Schuett, M. A., \& Hu, L. (2016). Do perceptions of time affect outbound-travel motivations and intention? An investigation among chinese seniors. Tourism Management, 53, 1-12.

23. Lynn, M. (1992). Scarcity's enhancement of desirability: The role of naive economic theories. Basic and Applied Social Psychology, 13(1), 67-78.

24. Moal-Ulvoas, G., \& Taylor, V. A. (2014). The spiritual benefits of travel for senior tourists. Journal of Consumer Behaviour, 13(6), 453-462.

25. Mroczek, D. K., \& Kolarz, C. M. (1998). The effect of age on positive and negative affect: A developmental perspective on happiness. Journal of Personality and Social Psychology, 75(5), 1333-1349.

26. Neumayer, E. (2006). Unequal access to foreign spaces: How states use visa restrictions to regulate mobility in a globalized world. Transactions of the Institute of British Geographers, 37(1), 72-84.

27. Neumayer, E. (2010). Visa restrictions and bilateral travel. The Professional Geographer, 62(2), 171181.

28. Nikitina, O., \& Vorontsova, G. (2015). Aging population and tourism: Socially determined model of consumer behavior in the "senior tourism" segment. Procedia - Social and Behavioral Sciences, 214, 845-851.

29. Patterson, I. (2007). Information sources used by older adults for decision making about tourist and travel destinations. International Journal of Consumer Studies, 31(5), 528-533.

30. Patuelli, R., \& Nijkamp, P. (2015). Travel motivations of seniors: A review and a meta-analytical assessment. Working paper, 1-15.

31. Pratkanis, A. R., \& Farquhar, P. H. (1992). A brief history of research on phantom alternatives: Evidence for seven empirical generalizations about phantoms. Basic and Applied Social Psychology, 13(1), 103-122.

32. Sangpikul, A. (2008a). A factor-cluster analysis of tourist motivations: A case of u.S. Senior travelers. Tourism, 56(1), 23-40.

33. Sangpikul, A. (2008b). Travel motivations of japanese senior travellers to Thailand. International Journal of Tourism Research, 10(1), 81-94.

34. Škare, V., \& Gospić, D. (2015). Dynamic pricing and customers> perceptions of price fairness in the airline industry. Turizam: znanstveno-stručni časopis, 63(4), 515-528.

35. Śniadek, J., \& Zajadacz, A. (2010). Senior citizens and their leisure activity-understanding leisure behaviour of elderly people in poland. Working paper, 193-204. 
36. UN. (2001). World population ageing: 1950-2050 (9789210510929). Retrieved from: http://www.un.org/esa/population/publications/worldageing19502050/

37. Vojvodic, K. (2015). Understanding the senior travel market: A review. Tourism in South East Europe, 3, 479-488.

38. Wang, K-C. (2006). Motivations for senior group package tour tourists. Journal of Tourism, 12(2), 119-138.

39. Watson, D., Clark, L. A., \& Carey, G. (1988). Positive and negative affectivity and their relation to anxiety and depressive disorders. Journal of abnormal psychology, 97(3), 346-353.

40. Watson, D., Clark, L. A., \& Tellegen, A. (1988). Development and validation of brief measures of positive and negative affect: The panas scales. Journal of Personality and Social Psychology, 54(6), 1063-1070.

41. Woo, E., Kim, H., \& Uysal, M. (2014). A measure of quality of life in elderly tourists. Applied Research in Quality of Life, 11(1), 65-82.

42. Zatlin, J. R. (2007). Scarcity and resentment: Economic sources of xenophobia in the GDR, 1971 1989. Central European History, 40(04), 683-720.

43. Zimmer, Z., Brayley, R. E., \& Searle, M. S. (1995). Whether to go and where to go: Identification of important influences on seniors' decisions to travel. Journal of Travel Research, 33(3), 3-10. 